\title{
РОЛЬ ЗАКЛАДІВ ОСВІТИ У ВИХОВАННІ ЗДОРОВОГО СПОСОБУ ЖИТТЯ У МОЛОДІ ЧЕРЕЗ РОЗВИТОК ДУХОВНОСТІ
}

К. Л. Чурпій

Кіровоградський інститут розвитку людини

\section{THE ROLE OF ESTABLISHMENTS OF EDUCATION IN EDUCATION OF HEALTHY WAY OF LIVING IN YOUNG PEOPLE THROUGN DEVELOPMENT OF SPIRITUALITY}

\author{
K. L. Churpiy
}

\author{
Kirovohrad Institute of Human Development
}

\begin{abstract}
У статті розглянуто доцільність виховання здорового способу життя в закладах освіти через розвиток духовності у молоді.

The article adduces the expediency of education of healthy way of living in establishments of education through development of spirituality in young people.
\end{abstract}

Вступ. Здоров'я населення - один з головних елементів національного багатства кожної країни. Здоров'я - це найвище благо, дароване людині Природою. Без нього життя не може бути повноцінним і щасливим. На жаль, досить часто ми в молодому віці- через необізнаність, а в дорослому - через легковажність бездумно тратимо цей дарунок, забуваючи, що повернути втрачене здоров'я дуже важко, а інколи неможливо.

Велика частка відповідальності за збереження і примноження цього багатства покладена на медицину. Проте система охорони здоров'я останніми роками 3 цим завданням або не справляється, або справляється частково. Адже стан здоров'я населення від медицини залежить лише на $10 \%$. Покладена відповідальність за здоров'я населення на медицину без участі в цьому процесі самого населення із самого початку приречена на невдачу. Тобто без формування здорового способу життя (ЗСЖ) всього населення неможливо поліпшити здоров'я населення.

Навчання здорового способу життя в основному проводиться силами медичних працівників переважно середнього медичного персоналу, який здебільшого не має спеціальної підготовки з формування ЗСЖ. Робота ця тримається на “голому” ентузіазмі виконавців [1].

Основна частина. Єдиного загальновизнаного визначення "здоровий спосіб життя" (ЗСЖ) не існує. У словнику “Основні терміни і поняття”, виданому
Мінохоронздоров'я РФ в 2001 р., “здоровий спосіб життя" - категорія загального поняття "способу життя”, включає сприятливі умови життєдіяльності людини, рівень їі культури і гігіснічних навиків, що дозволяють зберігати і укріплювати здоров'я, попереджати розвиток його порушень і підтримувати оптимальну якість життя".

На нашу думку, ЗСЖ - це життя людини з мінімальним впливом негативних чинників на організм по волі людини. Неможливо подолати хронічні неінфекційні захворювання, якщо не приділити серйозну увагу формуванню ЗСЖ, оскільки основний фактор ризику цих захворювань - спосіб життя людини. Тягар хвороб, пов'язаних з нездоровим способом життя населення України, такий: куріння - $13 \%$, зловживання алкоголем - $12 \%$, незаконне вживання наркотиків $3 \%$, недостатня фізична активність $-6 \%$ [2].

Якщо розглянути фактори, що впливають на здоров'я населення, то їх можна розділити на дві групи. Перша - шкідливі чинники, які впливають на здоров'я людини, але незалежні від неї: електромагнітні поля, радіація, забруднення навколишнього середовища промисловими викидами та інші. Друга група чинників, яким людина піддається свідомо і може завжди за їі бажання їх уникнути: куріння, вживання спиртних напоїв, низька фізична активність, вживання наркотиків, зараження ВІЛ-інфекцією, особливо серед споживаючих ін'єкційні наркотики, психоемоційні стреси, інше.

(С) К. Л. Чурпій 
Проте лише 8 \% молодих людей вважають здоров'я однією з головних цінностей життя. Випускники шкіл майже не мають уявлення про складові ЗСЖ, ï значення для збереження здоров'я.

Це диктує необхідність переорієнтації психосоціальних стереотипів мислення не тільки в школярів, але i в педагогів школи і вузів, батьків, шкільних лікарів.

В останні роки в Україні в умовах соціально-демографічної кризи питання збереження здоров' я молодого покоління, зокрема студентського віку, перетворилося на предмет особливої уваги. Незважаючи на широку систему впроваджених заходів на державному і регіональних рівнях, показники офіційної статистики і суб' єктивного самопочуття студентів характеризуються несприятливими тенденціями [3]. При цьому саме спосіб життя є одним з головних факторів незадовільного стану здоров'я молодого покоління.

I не випадково, що загальноприйняте у міжнародному співтоваристві визначення здоров'я, викладене в Преамбулі Статуту ВООЗ: “'Здоров’я - це стан повного фізичного, духовного і соціального благополуччя, а не лише відсутність хвороб або фізичних вад" [4]. Поряд з фізичним здоров'ям, яке в більшості закладається природою, соціальним благополуччям, яке забезпечує держава, здоров'я неможливе без духовного благополуччя. Однак духовне благополуччя не приходить саме. Лише через виховання в сім’і, школі, вузі можна виховати і сформувати духовно багату людину, яка буде дбати за своє здоров'я і вести здоровий спосіб життя - спосіб життя, в якому мінімізовані негативні впливи на людину з їі волі.

Тому одним з найважливіших питань у збереженні здоров' я є питання про відродження духовності. Духовність руйнувалася багато років. Духовність - це основа будь-якої цивілізації і руйнування духовності, ii знищення завжди веде до загибелі цивілізації. Ми опинилися за ситуації, коли суспільство знаходиться в стані кризи духовного стану населення. Надії людей і ідеали, які їм проповідували, не виправдані. Як наслідок цього духовність прийшла до занепаду. Видатний терапевт М. Я. Мудров стверджував, що одні люди захворюють від тілесних причин, а інші - від душевних обурень.

Наслідок такої духовної деградації є зростання наркоманії, збільшення хворих на СНІД, зростання поширеності алкоголізму, тютюнокуріння. За повідомленням Всесвітньої організації охорони здоров'я, від такої найбільш поширеної шкідливої звички, як тютюнокуріння, у світі щороку помирають 6,8 млн людей, в тому числі в Україні 120 тис. Серед юнаківстудентів палять цигарки 46,7 \%, а серед дівчат-сту- денток - 20,9 \% [5]. За статистичними даними, в Україні курить $21 \%$ жінок [6]. Поширення куріння серед жінок є трагедією людства. Жіночий організм більш чутливий до токсичного і канцерогенного впливу тютюну, а його наслідки обов' язково позначаються на здоров’ї майбутнього покоління.

Нами проведено обстеження 108 дітей з асоціальних сімей, матері яких вживали спиртні напої і курили в час вагітності і під час грудного вигодування. У дітей до одного року були виявлені наступні захворювання і патологічні стани: гіпотрофія у 66,6 \%, зниження маси тіла у 54,5 \%. Діти старше двох років мали зниження маси тіла у $39,2 \%$, рахіт спостерігався у 61,9 \% дітей. Зі всієї групи дітей анемія була в $35,1 \%$, відставання в психомоторному розвитку у $34,4 \%$, затримка мовного розвитку у $24,07 \%$.

При аналізі захворюваності у 480 дітей, матері яких курили під час вагітності, 15,83 \% віднесені до групи часто і довго хворіючих.

У всіх цих дітей уже порушене фізичне і частково психічне здоров' я, внаслідок свідомого нанесення їм шкоди по волі людини, в даному випадку матері. Чи може людина 3 високою духовністю бути убивцею своєї дитини. Відповідь одна - ні! Чи виростуть ці діти здоровими? Швидше, що ні. Адже тоді, коли закладалися підвалини їх фізичного здоров'я, воно руйнувалося їх бездуховними матерями.

На сьогодні формування ЗСЖ і забезпечення повноцінного фізичного розвитку дітей, охорона та зміцнення їхнього здоров'я має стати одним із пріоритетних напрямів виховання дітей починаючи від їх народження. Але це можливо зробити лише при умові формування фізичного, соціального і духовного розвитку разом, але в першу чергу духовного.

На жаль, за роки тотального атеїзму у вітчизняному вихованні сталося забуття і втрата православних традицій духовності і вільнодумства, святості і подвижництва. Сьогодні, за даними соціологів, у товаристві домінує тип людини масової культури, яка втратила риси національної самобутності, відрізняється авторитаризмом при одночасному переживанні комплексу власної неповноцінності, має неглибоку історичну пам'ять, насторожено ставиться до оточення. Завдання формування духовної культури особи, що спирається на національні витоки, відновлення на цій основі особової цілісності стало як ніколи актуальним.

Ведення здорового способу життя прямо впливає на збереження, зміцнення і відновлення здоров' я $\mathrm{i}$ опосередковано - на успіх у навчанні, сприяє інтелектуальному й духовному розвитку особистості. 
На думку П. Ф. Каптєрєва, головне завдання шкільного навчання $\epsilon$ не "вивчення предметів, а $\epsilon$ розвиток особистості предметами; на першому місці стоїть особа, суб'єкт, його інтереси, а предмети - на другому, предмети - тільки засоби, мета - особа і іiі розвиток" [7].

Виховання здорового способу життя в учнів і студентів забезпечить збереження їх здоров'я і опосередковано забезпечить успіх у навчанні, буде сприяти розвитку інтелектуального здоров'я і високорозвиненого суспільства. В цьому величезна роль відводиться учителю, педагогу. Він - постійний приклад для своїх учнів. Відсутність належних моральних якостей, інтелектуальні лінощі, безвілля учителя згубним чином впливають на вихованців. Така людина не здатна виховати духовну особу і проповідувати здоровий спосіб життя.

К. Д. Ушинський підкреслював: виховна сила виходить тільки з живого джерела людської особистості, впливати на виховання особистості можна лише особистістю. В очах дитини лише той учинок заслуговує на наслідування, який здійснений авторитетною і поважаною людиною. Тільки високодуховна, гуманістично спрямована особистість дорослої людини

\section{Література}

1. Ринда Ф. П. Нагальні питання формування здорового способу життя в Україні / Ф. П. Ринда, А. А. Григоренко // Україна. Здоров’я нації. - 2012. - № 2-3. - С. 213-217.

2. Arnaudova Albena. 10 вопросов о здравоохранении в странах - новых соседях ЕC / Arnaudova Albena; пер. с англ. - Копенгаген : ЕРБВОЗ, 2006. - 292 с.

3. Отношение студентов к здоровью и здоровому образу жизни / Н. И. Белова, С. П. Бурцев, Е. А. Воробцова, А. В. Мартыненко // Проблемы социальной гигиены, здравоохранения и истории медицины. -2006. - № 1. - С. 14 15.

4. О политике Всемирной организации здравоохране- здатна створювати і підтримувати атмосферу доброзичливості, любові, творчості і завдяки цьому сприяти духовному піднесенню вихованця [8].

Духовне виховання молоді на власному досвіді і прикладі викладача, яке продовжується і доповнюється під час навчання в школі і вузі, буде сприяти вихованню здорового способу життя. Для формування здорового способу життя необхідне постійне духовне виховання молоді. Формування здорового способу життя у молоді має включати у закладах освіти заходи по формуванню особистої мотивації до збереження і зміцнення свого здоров' я. Впровадження системи навчання по збереженню здоров'я і вихованню ЗСЖ в кожному навчальному закладі із загостренням уваги на тому, що кожна людина має свідомо дбати за своє здоров' я і вести ЗСЖ, дасть змогу виховати здорове покоління. Формування ЗСЖ у молоді можливе лише через розвиток їх духовності.

Висновки: 1. Формування і розвиток духовності у молоді в закладах освіти з метою формування ЗСЖ має бути одним з пріоритетних питань закладу.

2. Виховання ЗСЖ у молоді через розвиток духовності забезпечить розвиток високодуховного суспільства і збереження здоров'я нації.

ния. “Здоровье для всех до 2000 года” // Медицинские вести. -1997 . - № 1. - С. 22-23.

5. Чоп' як В. В. Ризик розвиткупатологічних станів у студентської молоді під впливом тютюнопаління / В. В. Чоп’як, С. О. Зубченко // Український медичний часопис. 2011. - № 1(81).

6. A Report of the Surgeon General (2001) Women and Smoking. - http//www.ncbi.nlm.nih.gov/books/NBK44303/

7. Каптерев П. Ф. // Школа и жизнь. - 1911. - № 10.

8. Помиткін Е. О. Психологія духовного розвитку особистості : монографія / Е. О. Помиткін. -К. : Наш час, 2007. $280 \mathrm{c}$. 